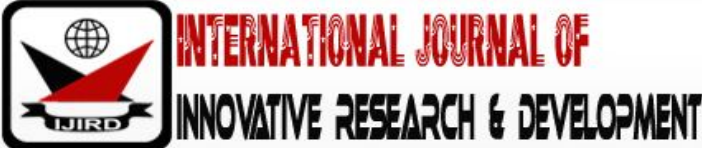

ISSN 2278 - 0211 (Online)

\section{Challenges of Management towards Financial Motivation of Tradesmen and the Methods of Overcoming the Challenges for Effective Project Delivery, Nigeria}

\author{
Ogbuiyi Obianuju.J. \\ Teacher, Department of Education, Post Primary Schools Services Commission, Nigeria \\ Okolie Kelvin .C. \\ Senior Lecturer, Department of Building, Nnamdi Azikiwe University, Nigeria
}

\begin{abstract}
:
Aim: This Study identifies Challenges of Management towards Financial Motivation of Tradesmen and the Methods of overcoming the challenges for effective delivery of projects by construction companies in Anambra state Nigeria. Study Design: The study was a survey research. Questionnaires were distributed randomly to management staffinselected construction firms in Anambra State, Nigeria.

Place and Duration of the Study: The study was conducted in Anambra State Nigeria and it lasted for a period of five months.

Methodology: A total of 36 questionnaires were distributed to the respondents, out of which 17 were correctly completed, returned and found useful. Data collected were analyzed and presented using tables, mean, percentages, pie charts, bar charts and Relative Important Index (RII).

Results: The study revealed company's expenditure as the most challenging factor inhibiting management effort towards tradesmen motivation( 0.91 ), followed by prolonged decision making (0.80); Attitude problem of tradesmen (0.78); diverse workforce (0.74); poor financial strength (0.74); short nature of projects (0.69). The least among the factors is achievement anxiety (0.25). Also construction managers in the area perceived grants from government and minimization of unnecessary expenditures as one of the best ways of overcoming the challenges associated with tradesmen motivation in construction project delivery.

Conclusion: The study was concluded by recommending that management make serious efforts to overcome the challenges associated with tradesmen motivation for effective delivery of projects especially by requesting for grants from government; prioritizing expenses and proper project planning in order to minimize cost and time overrun as well as bad quality of executed projects.
\end{abstract}

Keywords: Motivation, effective project delivery, management challenges with respect to tradesmen motivation

\section{Introduction}

Every organization is concerned with what should be done to achieve sustained high levels of performance through its workforce. This means giving close attention to how individuals can best be motivated through such means as incentives, rewards, leadership, etc., and the organizational context within which they carry out the work (Amstrong, 2006). With positive motivation philosophy and practice in place, productivity, quality and service should improve because motivation helps people towards achieving goals, gaining positive perspective, creating the power for change, building self-esteem and capability, and managing their development and helping others (Adjei, 2009).

The role of management is to apply organizational resources which include human resources to achieve organizational objectives (Parkin, Tutesigensi and Buyukalf, 2009). For increased productivity which is one of the organizational goals, work force motivation is an influencing factor (Parkin, et al., 2009). In order to ensure that people employed in the organization perform optimally towards the realization of organizational goals, they need to be motivated to work. An employee must be motivated towards his role and work in an organization, if no motivation is present in an employee, then that employee's quality of work or overall work performance will deteriorate (Agarwal and Agarwal, 2013).Motivation is defined as the processes that account for an individual's intensity, direction, and persistence of efforts towards attaining a goal (iEduNote, 2019).

Most contracting organizations have tried using financial incentives like bonus system, allowances parks, and salaries to motivate their workforce, but all these have proved abortive. The complexity of the construction project delivery is one of the major challenges in applying financial incentives. Construction projects emerge in fragments (Mitropoulous and Tatum, 2000). Disjointed relationship between contracting parties, misalignment of objectives, and risk adverse behaviours characterized construction projects (Rahman and Kumaraswamy, 2004). Similarly, adversarial 
business environments in the construction industry are a major barrier to continued growth and diffusion of new innovation (Anderson, Cook, and Marceau, 2004). The difficulty in assessing performance in highly interdependent teams compounds the challenge as individual output may be almost indistinguishable from group output (Howard, Turban, and Hurley, 2002).

Time, Cost and quality targets are recognised to be the major criteria used to measure project delivery level of success (Dissanya and Kumaraswamy, 1999). John, Abdulateef and Abdulganiyu (2015) asserts that the clients of building projects are primarily interested in their projects being delivered within a short time for an effective lower cost, and at a higher quality.

Unfortunately, management of building projects is faced with lots of challenges with respect to tradesmen motivation which affects the effective delivery of projects. This study attempts to identify the factors challenging management efforts with respect to tradesmen motivation and the methods of overcoming the challenges. Particular attention is devoted to effective project delivery and management challenges with respect to tradesmen motivation.

\section{Literature Review}

\subsection{Effective Project Delivery}

A successful project means that the project has accomplished its technical performance, maintained its schedule, and remained within budgetary costs (research Clue.com, 2019). Time, cost and quality target are recognized to be the major criteria to measure project delivery level of success. These three major variables are of primary concern to the main parties involved in the procurement of building project i.e. client and contractors (Dissanaya and Kumaraswamy, 1999). Cost, Time and Quality can be simply identified as three points comprised in a triangle, underestimating any of them will definitely cause resultant negative effects on the remaining two (Hugh and Williams, 1999). Delay in the completion of construction project can be a major problem for construction companies, leading to costly and adverse relationships among project participants (Alwi and Hampson, 2003). Cost overrun implies added costs over and above the cost agreed upon at the outset, resulting in less returns on investment. To the end-user, the added costs are passed on as higher rental costs; To professionals, cost overrun imply inability to deliver value for money and could well tarnish their reputation and results in loss of confidence attributed to them by clients.; To the contractors it implies loss of profit through penalties for no-completion, and negative 'word of mouth' that could jeopardize chances of winning further jobs, if at fault (Mbachu and Nkado, 2004).

In order to deliver projects within budgeted cost, within the estimated time and of proper quality standards, the management of construction project should align the project objectives with motivation, since lack of motivation can result in ineffective project delivery.

\subsection{Management Challenges with Respect to Tradesmen Motivation}

Motivation is a very powerful tool for increasing organizational success (Tizazu, 2015; Kirstein, 2010; Parkin, et al., 2009; Pike, 2001). Unfortunately, managers fail to utilize motivation in order to retain their employees (Bassel et al., 2008). Management of construction projects are faced with a lot of challenges which makes it difficult to adopt appropriate motivational strategies. Some of the problems limiting management performance in managing projects through motivation are caused by the construction industry related factors while some are caused by employee related factors. Other challenges facing construction management team can be attributed to the financial strength and the competitive nature of construction organizations (Mansfield and Odeh 1991; Nordmeyer 2017; Osuji 2015).

The study by Osuji (2015), on the motivational factors of Employee-consultants in the Nigerian construction industry revealed that worker's wages, company's expenditures and low availability of income affected management performance in motivating their employees. He therefore suggests that it would be necessary for the management of construction firms to apply a high level of managerial skills to permit them deal with their employee motivation.

Nordmeyer (2017), believed that personal problems of employees can limit management effort in adopting proper motivational techniques and listed: low self-confidence, low expectations for success, lack of interest, achievement anxiety and fear of failure as factors with employees which might make it difficult for any motivational technique to work affectively.

The unique nature of construction industry is also seen as a major challenge affecting the success of any motivation technique. Hazeltine (1976), recommended that construction management should fully understand the unique characteristics of construction industry before developing motivation policies. Mansfield and Odeh (1991), asserted that the construction industry is characterized by short term employment which is often based on the life of the project or part of it and the employees are not allowed sufficient time to integrate with their organization in order to develop a proper understanding of the job. Subsequently, Halepota (2005), believed that environmental factors is one of the factors that affect motivation which cannot be controlled by management.

\section{Methodology}

The study is carried out in Anambra State, Nigeria, using a survey method. The name Anambra state was derived from the Anambra River (Omambala) which flows through the area and is a tributary of the River Niger. Anambra state is located between latitudes $05^{\circ} 40^{\prime} \mathrm{N}$ and $07^{\circ} 10^{\prime} \mathrm{N}$ and $06^{\circ} 35^{\prime} \mathrm{E}$ and $07^{0} 20^{\prime} \mathrm{E}$ (see fig. 1 and 2). The state shares boundaries with Delta to the West, Imo to the South, Enugu to the East and Kogi to the North. It has a total land mass of 4,416 km and situated on the Eastern side of River Niger. The state has 177 communities (towns) in 21 Local Government Areas. It comprises of three major towns namely; Awka, its capital city, and the seat of Government, the commercial town of 
Onitsha and the industrial city of Nnewi. According to the NPC (2006) Anambra State has a population 4, 182, 032 made up of 2,007,391 and males 2,174, 64 females, which makes it the most populous state nationwide. It also has estimated average population density 1500 - 2000 persons per square kilometer, making it the second most densely populated state in Nigeria, after Lagos state. With an annual population growth rate of 2.21 percent per annum, Anambra has over $60 \%$ of its people living in urban area making it one of the most urbanized places in Nigeria.

Anambra state is in the tropical zone of Nigeria, with the distinct seasons, dry and rainy seasons from December to April and May to October respectively while annual precipitation ranges from $15000 \mathrm{~mm}$ to $2000 \mathrm{~mm}$ rainfall with July as the rainiest month. According to him, humidity is relatively high between $65-80 \%$ throughout the year; daily temperatures up to $25^{\circ} \mathrm{C}$ are recorded on very hot days in January and March. Anambra state has fairly good subsoil strata. It exhibit quality sub base foundation soil for buildings and construction work: extensive construction activities and concentration of industry participants such as clients, contractors and professional consultants are found in the state capital of Awka and other commercial towns such as Onitsha and Nnewi. The contribution of the construction industry over the past few years represents a significant percentage of the state Gross Domestic Product (GDP). Construction activities also provide a substantial source of employment, especially unskilled labour.

The population of this study constitutes of management personnel from five construction companies located in the state. The population of these managers as obtained from their various companies is thirty. (See table 1).

The study includes the entire population of managers from the companies and does not determine sample size since the population is relatively small.

Data were collected through structured questionnaire administered to the respondents. Accordingly, out of a total 36 questionnaire administered, only 17 are returned, completed and found useful.

Consequently, table; mean; percentage; histogram and pie chart are used for data presentation. However, Relative Important Index (RII) was used for ranking and computed using the formula:

Where,

$$
\mathrm{RII}=\frac{\sum F X}{A * N}
$$

$\sum \mathrm{FX}=$ Weight given to each statement by respondents and ranges 1-5

$\mathrm{A}=$ Higher Response Integer

$\mathrm{N}=$ Total Number of Respondents

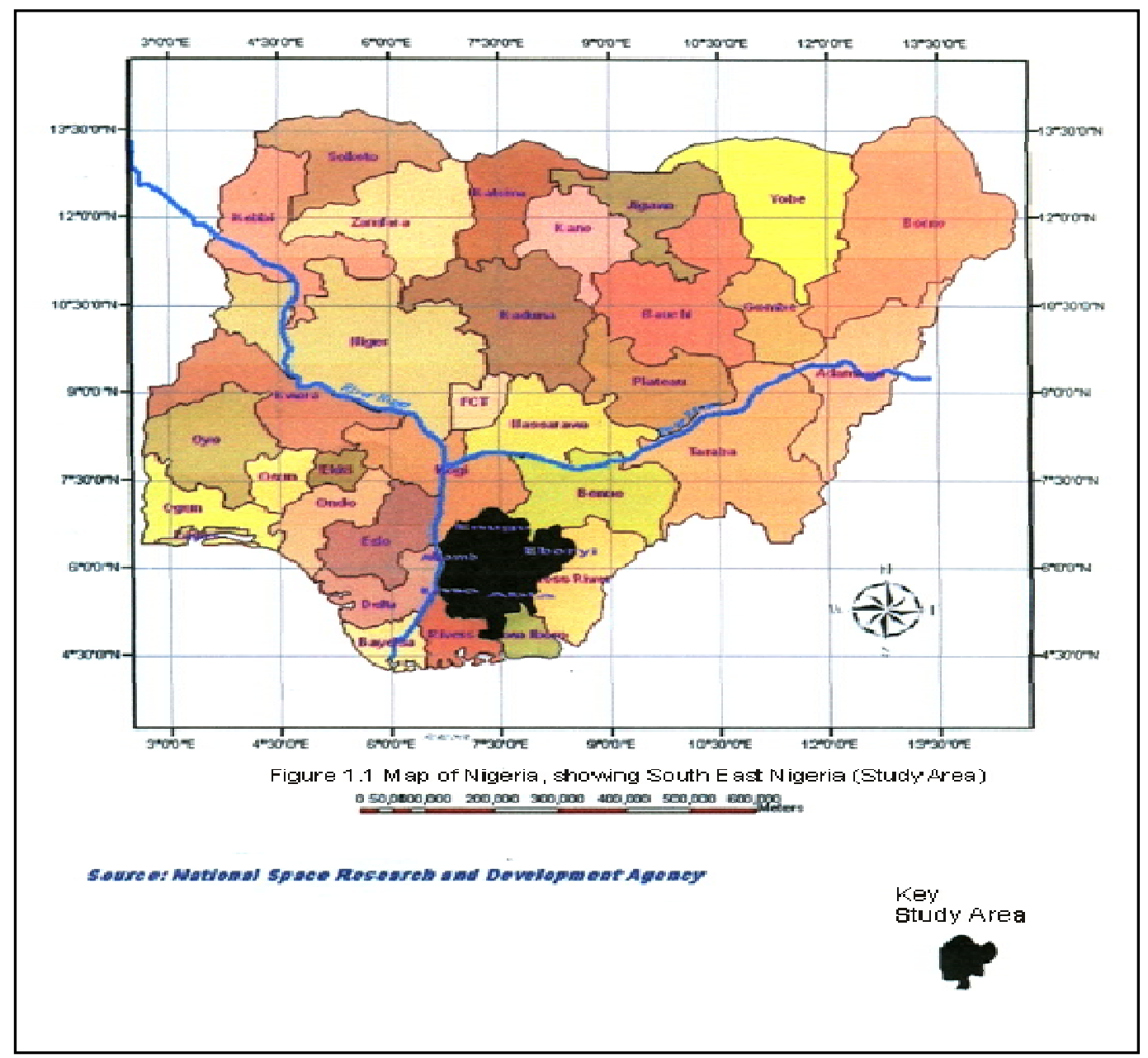

Figure 1

Source: National Space Research and Development Agency 


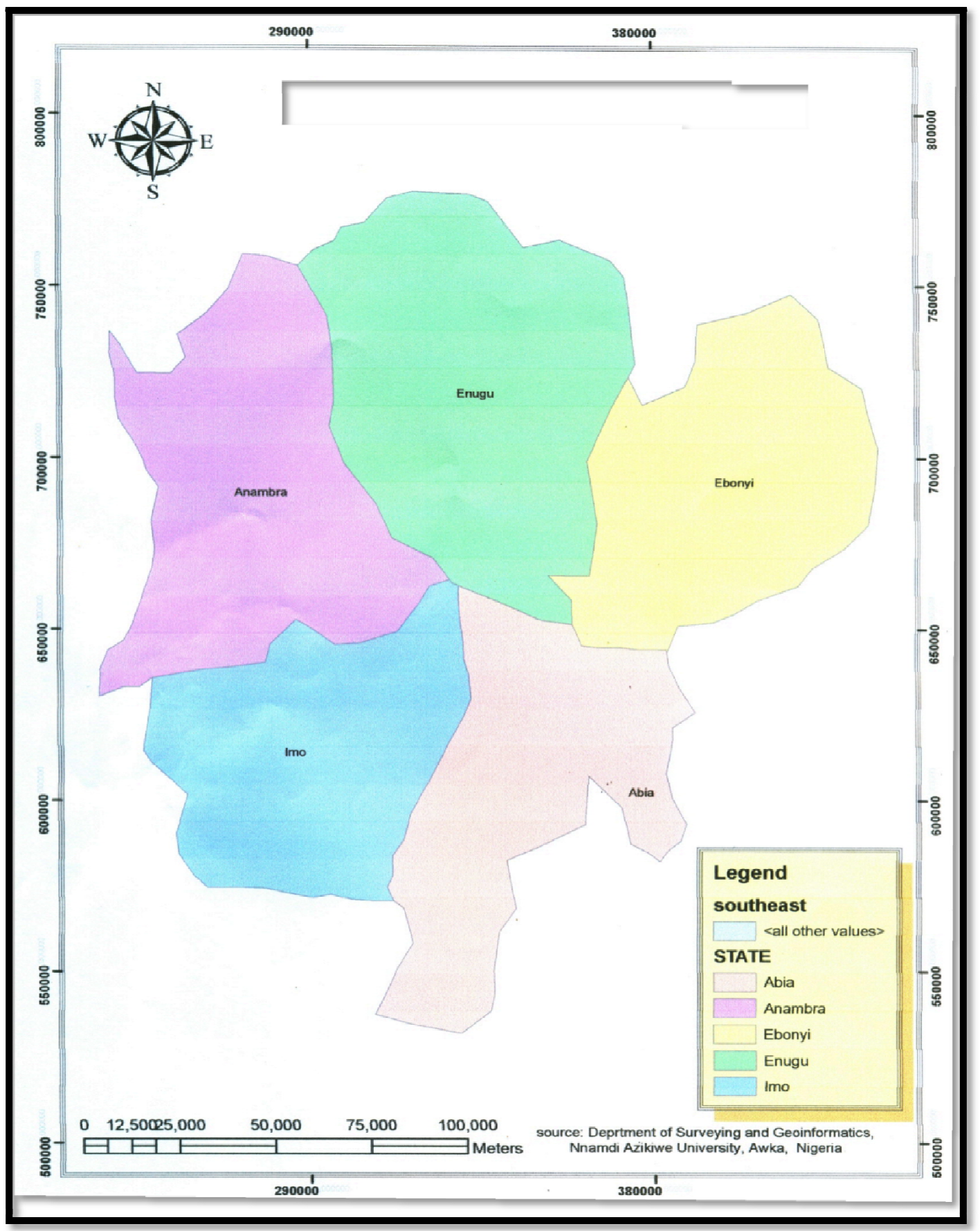

Figure 2: Map of South-East Niagara the Five States

Source: Department of Surveying and Geoinformatics Nnamdi Azikiwe University, Awka, Nigeria

\section{Result and Discussion}

The result in table 3indicates Company's expenditure as the most challenging factor inhibiting management efforts towards the motivation of tradesmen (0.91), followed by Prolonged decision making (0.80); Attitude problem of tradesmen (0.78); Diverse workforce (0.74); Poor financial strength (0.74); Short nature of projects (0.69). The least among the factors is Achievement anxiety (0.25).

Table 4 reveals that Grants from government ranked first among the methods of overcoming the challenges faced by management regarding tradesmen motivation (4.82), followed by Minimization of unnecessary expenditures; Proper project planning (4.12); Proper recruitment procedure (3.94); Quick decision making (3.35). The least in their consideration is disengaging unmotivated employees (1.65).

Figure 3 shows a bar chart on the population distribution of the respondents as represented in table 1, while figure 4 discloses the distribution of questionnaire to the respondents as shown in table 2. 


\begin{tabular}{|c|c|c|c|}
\hline S/ N & Management & Population & Percentage \\
\hline 1 & Managing Directors & 5 & 16.7 \\
\hline 2 & Head of Operations & 8 & 26.7 \\
\hline 3 & Project Managers & 7 & 23.3 \\
\hline \multirow{2}{*}{4} & Site Engineers & 10 & 33.3 \\
\hline & Total & 30 & 100 \\
\hline
\end{tabular}

Table1: Population Distribution of the Respondents

\begin{tabular}{|c|c|c|}
\hline Questionnaire & Frequency & Percentage \\
\hline Number of questionnaire returned & 17 & 47.2 \\
\hline Number of questionnaire returned not returned & 19 & 52.8 \\
\hline Total & 36 & 100 \\
\hline
\end{tabular}

Table 2: Questionnaire Distribution to Respondents

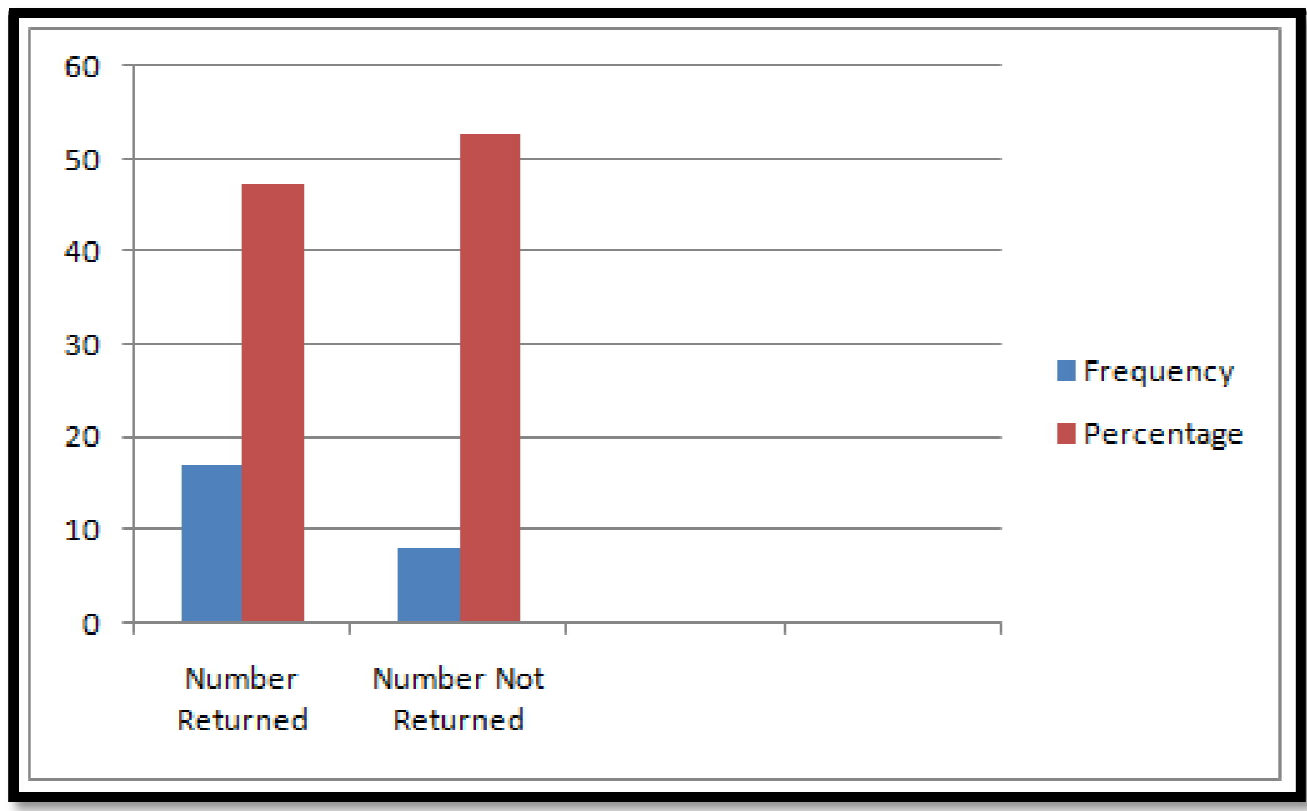

Figure3: Population Distribution of the Respondents Source: Researcher's Field Survey

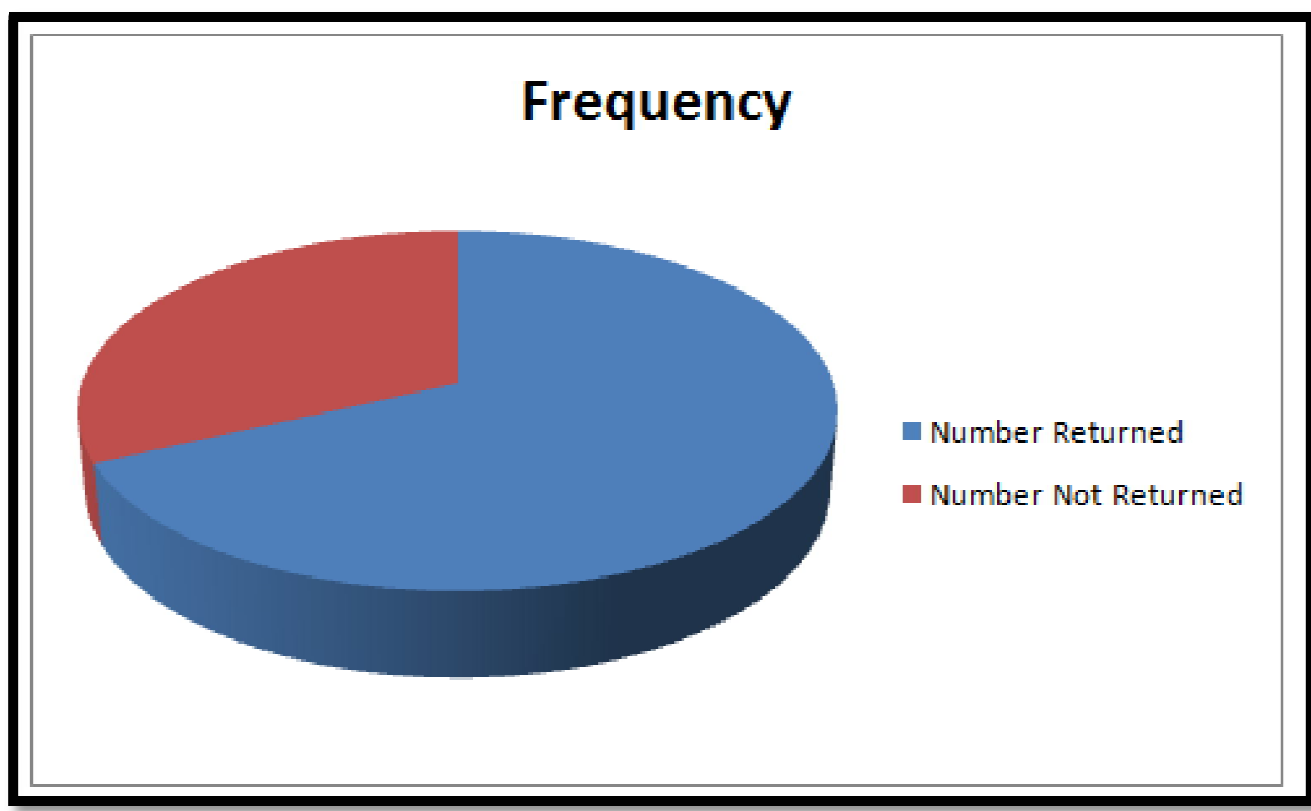

Figure4: Pie Chart Showing Distribution Of Questionnaire Source: Researcher's Field Surveys 


\begin{tabular}{|c|c|c|c|c|c|c|c|c|c|c|c|}
\hline \multirow[t]{2}{*}{$\mathbf{S} / \mathbf{N}$} & \multirow[t]{2}{*}{ Challenging Factors } & \multicolumn{5}{|c|}{ Frequency } & \multirow[t]{2}{*}{$\sum \mathrm{F}$} & \multirow[t]{2}{*}{$\sum \mathrm{FX}$} & \multirow[t]{2}{*}{$\bar{X}$} & \multirow[t]{2}{*}{ RII } & \multirow[t]{2}{*}{ Rank } \\
\hline & & 5 & 4 & 3 & 2 & 1 & & & & & \\
\hline 1 & Hiring the wrong people from the start & 6 & 4 & 1 & 2 & 4 & 17 & 57 & 3.35 & 0.67 & 7th \\
\hline 2 & Poor Financial Strength & 10 & 2 & 0 & 0 & 5 & 17 & 63 & 3.71 & 0.74 & 4th \\
\hline 3 & Company's Expenditures & 14 & 1 & 0 & 1 & 1 & 17 & 77 & 4.53 & 0.91 & $1 \mathrm{st}$ \\
\hline 4 & Prolonged Decision Making. & 8 & 5 & 2 & 0 & 2 & 17 & 68 & 4.00 & 0.80 & 2nd \\
\hline 5 & Short Nature of Projects & 4 & 4 & 5 & 4 & 0 & 17 & 59 & 3.47 & 0.69 & 6th \\
\hline 6 & Market Changes & 0 & 0 & 1 & 4 & 12 & 17 & 23 & 1.35 & 0.27 & 9th \\
\hline 7 & Low Self Confidence of Tradesmen & 0 & 0 & 2 & 5 & 10 & 17 & 26 & 1.53 & 0.31 & 8th \\
\hline 8 & Employee's Lack of Interest & 0 & 1 & 1 & 3 & 12 & 17 & 25 & 1.47 & 0.29 & 10th \\
\hline 9 & Achievement Anxiety & 0 & 0 & 1 & 2 & 14 & 17 & 21 & 1.24 & 0.25 & 11th \\
\hline 10 & Diverse Workforce & 5 & 5 & 4 & 3 & 0 & 17 & 63 & 3.71 & 0.74 & 4th \\
\hline 11 & Attitude Problem of Tradesmen & 5 & 5 & 4 & 1 & 2 & 17 & 66 & 3.88 & 0.78 & $3 \mathrm{rd}$ \\
\hline
\end{tabular}

Table 3: Management response on the Challenging factors inhibiting tradesmen Motivation

5. MC- Most Challenging; 4. C- Challenging; 3. NC- Not Challenging; 2. NVC- Not Very Challenging; 1. NCA- Not Challenging at All

\begin{tabular}{|c|c|c|c|c|c|c|c|c|c|c|c|}
\hline \multirow{2}{*}{$\mathbf{S} / \mathbf{N}$} & \multirow{2}{*}{$\begin{array}{l}\text { Methods of overcoming } \\
\text { tradesmen motivation } \\
\text { challenges }\end{array}$} & \multicolumn{5}{|c|}{ Frequency } & \multirow[t]{2}{*}{$\sum \mathrm{F}$} & \multirow[t]{2}{*}{$\sum \mathrm{FX}$} & \multirow[t]{2}{*}{$\bar{X}$} & \multirow[t]{2}{*}{ RII } & \multirow[t]{2}{*}{ Rank } \\
\hline & & 5 & 4 & 3 & 2 & 1 & & & & & \\
\hline 1 & Proper recruitment procedure & 9 & 3 & 2 & 2 & 1 & 17 & 68 & 3.94 & 0.79 & 4th \\
\hline 2 & Grants from government & 14 & 3 & 0 & 0 & 0 & 17 & 82 & 4.82 & 0.96 & 1st \\
\hline 3 & $\begin{array}{l}\text { Minimization of unnecessary } \\
\text { expenditures }\end{array}$ & 10 & 5 & 2 & 0 & 0 & 17 & 76 & 4.47 & 0.89 & 2nd \\
\hline 4 & Quick Decision Making. & 4 & 6 & 3 & 0 & 4 & 17 & 57 & 3.35 & 0.67 & 5th \\
\hline 5 & Proper Project Planning & 8 & 7 & 0 & 0 & 2 & 17 & 70 & 4.12 & 0.82 & 3rd \\
\hline 6 & Organizing Employee Seminar & 0 & 1 & 3 & 5 & 8 & 17 & 31 & 1.82 & 0.36 & 7th \\
\hline 7 & $\begin{array}{l}\text { Disengaging unmotivated } \\
\text { employees }\end{array}$ & 0 & 0 & 4 & 3 & 10 & 17 & 28 & 1.65 & 0.33 & 8th \\
\hline 8 & Acquisition of loans & 3 & 5 & 2 & 4 & 3 & 17 & 52 & 3.06 & 0.61 & 6th \\
\hline
\end{tabular}

Table 4: Management response on methods of overcoming challenges inhibiting tradesmen motivation 5. SA- Strongly Agree; 4. A- Agree; 3. NO- No Opinion; 2. DA- Disagree; 1. SDA- Strongly Disagree

\section{Conclusion and Recommendation}

Construction Managers in the study area are faced with a lot of challenges towards the motivation of tradesmen which affects the effective delivery of projects. The most challenging factor is company's expenditure which does not avail the companies extra fund to financially motivate tradesmen outside their usual wage. Management also delays in making financial decision which affects the motivation of tradesmen during the project delivery period. Management personnel believed that grants from government and minimization of unnecessary expenditures were one of the best ways of overcoming the challenges associated with tradesmen motivation. The study therefore recommends thatConstruction companies in the study area:

- Request for grants from government to help boost their financial strength.

- Prioritize expenses and avoid the unnecessary ones.

- Quickens decision making relating to each project.

- Engage in proper project planning before commencement of each project and allow some cost in the contract sum

- for financial motivation of tradesmen during project execution.

- Review Company's recruitment procedure to ensure that the right people are hired from the start.

Thus, if management of construction companies in the study area can overcome the challenges associated with tradesmen motivation during project delivery, it will be faced with a motivated workforce. When the tradesmen are motivated, they are productive. Productive tradesmen help construction managers to effectively deliver projects within the budgeted cost, agreed time frame and approved quality standards, for the good of the project parties. All these mean effective delivery of projects by companies in the study area. Effective project delivery enhances company's reputation and it can be achieved through tradesmen motivation. 


\section{References}

i. Amstrong, H. (2006). Human Resource Management Practice. London. Kogan Page.

ii. Adjei, E.A (2009). Motivational Strategies to Improve Productivity in the Construction Industry in Ghana. An M.Sc. Thesis submitted to the Department of Building Technology, Kwameh Nkrumah University of Science and Technology, Kumasi.

iii. $\quad$ Parkin, A.b., Tutesigensi, A. and Buyukalp, A.I. (2009). Motivation among Construction workers in Turkey. In: Dainty, A.R.J. (ed.). Proceedings of 25th ARCOM Conference, 7-9 September, Nottingham, U.K.

iv. Agarwal, S. and Agarwal, K. (2013). Motivation- An Important key to improve Employee Performance. International Journal of commerce, Business and Management, 2(6), 437.

v. iEduNote (2017). What is Motivation? Definition, Features, Objectives. Online. Retrieved from: http// iedunote.com/ motivation. (Accessed, September 2019).

vi. Mitopolous, P. and Tatum, C.B. (2000). Management Driven Integration. Journal of Management in Engineering. 16(1): 48-58.

vii. Rahman, M.M., and Kumaraswany, M.M. (2004). Contracting relationship Trends and Transitions. Journal of Management in Engineering. 20(4): 147-161.

viii. Anderson, P.H., Cook, C. and Marceau, J. (2004). Dynamic Innovation Strategies and Stable networks in the Construction industry: Implementing solar Energy Projects in the Sydney Olympic Village. Journal of Business Research. 57(4): 351-360.

ix. Howard, L.W., Turban, D.B., and Hurley, S.K. (2002). Cooperating teams and Competing rewards Strategies: Incentives for team Performance and firm Productivity. Journal of Behavioral and Applied Management. 3(3): 248263.

x. Dissanayaka, S.M and Kumaraswamy, M. (1999). Comparing Contributors to Time and Cost Performance in Building Projects. A Journal of Building and Environment, 34, 31 - 42.

xi. John, E.I., Abdullateef, A.S., and Abdulganiyu, A.O. (2015). A study of Time and Cost Relationship of Private Building Projects in Abuja. International Journal of Construction Engineering and Management. 4 (1), 26 - 34.

xii. Research Clue.Com (2019). The Effect of Timely Delivery of Construction Projects on the Economic Developmentof Nigeria (A case study of some selected project supervisors in Julius Berger PLC and Marlum Construction Company). Online. Retrieved From:www.https:// nairaproject.com. (Accessed November 2019).

xiii. Hughes, T and Williams, T. (1991). Quality Assurance. UK: UK Professionals Books.

xiv. Alwi, S. and Hampson, K. (2003). Identifying the Important Causes of Delays in Building Construction Projects, The 9th East Asia-Pacific Conference on Structural Engineering and Construction, Bali - Indonesia, 1-7. Online. Retrieved from: http:/ / eprints.qut.edu.au/ 4156/ 1/ 4156.pdf. (Accessed March, 2017).

xv. Mbachu, J.I.C. and Nkado, R.N. (2004). Reducing Building Construction Costs: the View of Consultants and Contractors, The international Construction Research Conferenceof the Royal Institution of Chartered Surveyors, COBRA, 7-8 Sept 2004, Leeds,United Kingdom.

xvi. Tizazu, K. (2015). Employee Motivation and its Effect on Employee Retention in Ambo Mineral water Factory. International Journal of Advanced Research in Computer Science and Management Studies, 3 (3), 10-11.

xvii. Kirstein, m. (2010). The role of motivation in Human Resource Management: Importance of Motivation Factors among future business persons. M.Sc. Thesis submitted to Aarhus School of Business, Aarhus University.

xviii. Pike, A. (2001). People risks. London, Penguin Books.

xix. Bessell I, Dicks B, Wysocki A, Kepner K. (2008). Understanding Motivation: An Effective Tool for Managers. Online. Retrieved from: http:/ / edis.ifas.ufl.edu/ HR017. Accessed January 2015.

xx. Mansfield, N R and Odeh, N S (1991) 'Issues Affecting Motivation on Construction Projects' ButterworthHeinemann Ltd, 9(2) 93-98.

xxi. Nordmeyer, B. (2017). Challenges in Employee Retention. Online. Retrieved from: http/ dinan.export.teofila.pw. (Accessed February, 2018).

xxii. Osuji, E.C. (2015). Evaluating the Motivational Factors of Employee-Consultants in the Nigerian Construction Industry. An M.Sc. Thesis Submitted to Department of Building Ahmadu Bello University Zaria.

xxiii. Hazeltine, C S. (1976). Motivation of Construction Workers. Journal of Construction Engineering and Management, 102(3) ,497-509.

xxiv. Halepota, H. A. (2005). Motivational Theories and Their Application in Construction. Journal of Cost Engineering, 47(3),14-18.

xxv. National Space Research and Development Agency (2014). Map of Nigeria showing the South East. Awka, Ezeokonkwo.

xxvi. Department of Surveying and Geoinformatics (2018). Map of South East Nigeria showing Anambra State. Awka, Ugochukwu. 